Academy being represented on this by one member only, if it concerns itself with only one of the Sections of Literature or Science; it will send two delegates when it is concerned with both Sections. Amongst the eighteen Academies, twelve belong to both Sections and consequently will send two delegates to the committee. Of the other six, four, namely the Royal Society of London, the Academy of Sciences of Paris, the Academy of Stockholm, and the National Academy of Washington, belong to the Section of Science alone, and two, the Academy of Inscriptions and Literature, and the Academy of Moral and Political Sciences, belong to the Section of Literature. Hence the committee will consist of thirty delegates, of which sixteen will belong to the Section of Science, and fourteen to that of Literature. In full committee the two delegates of one Academy will have only a single vote. After delay, inevitable in such cases, all the Academies, with the exception of two or three, have sent in the names of their delegates. The delegate of the principal Academy will take the chair at the committee of the Association, the principal Academy being that of the place in which it is proposed to hold the next general meeting.

The Conference of Wiesbaden having decided on a resolution to which we can here only draw attention, that the first general meeting of the International Association should be held in Paris this year, a difficulty has arisen not foreseen when the provisional rules were drawn up. Three Parisian Academies having joined the Association, it is necessary to decide to which shall be assigned the Presidency on this occasion. The delegates of the three Academies of the Institute of France have met, and have unanimously decided to confer for this year the presidency of the Association upon the Academy of Sciences, which was the first to join the Association, and, moreover, has taken an active part in the discussions, at the conclusion of which the Association was constituted.

It has been further decided that the first Session of the committee shall be held in Paris towards the end of July, the first meeting being fixed for Tuesday, July $3 \mathrm{I}$, at 9.30 a.m., at the Palais de l'Institut.

The agenda for the first meeting will include the preparation of a scheme of government for the committee, the settlement of the exact date and the order of the day for the next general meeting. The Royal Society of London, which has taken so active a part in the formation of the Association, has already announced a scheme which it proposes to submit for approval to this next general meeting; it concerns the measurement of an extended arc of a meridian in the interior of Africa.

The Academy, by the act of joining, has subscribed to the rules of the new Association. There is no occasion to recall here with what prudence and moderation they have been drawn up. The object of the Association is to prepare and promote scientific work of general interest which may be proposed by one of the constituent Academies, and generally to facilitate scientific relations between different countries. In any particular case, each Academy reserves to itself the right to give or refuse its support, or decide the choice of methods and the means to be employed.

If these principles are followed, the Association will become a powerful instrument of study, of concord and of scientific progress; it will rapidly take its place in the front rank of those international scientific associations, the rôle of which must necessarily be satisfactory.

Faithful to the principles which they have always followed, the three Academies of the Institute of France, called by the nature of their studies into the Association, will strive to assure it the success and influence which have been desired for it by its promoters.

Finally, attention may be directed to a particular clause in the rules which will interest some of our NO. 1602 , voL. 627 colleagues. For taking into consideration the study or preparation of scientific enterprises or researches of international interest, upon the proposition of one or more of the associated Academies, special international commissions may be instituted either by the general meeting or one of its two Sections, or, in the interval between two general meetings, by the committee or one of its two Sections.

\section{THE NEW PHYSICAL LABORATORY AT OWENS COLLEGE.}

WENS COLLEGE recently held high festival on the occasion of the opening, by Lord Rayleigh, of the new physics laboratories. Of these, a preliminary account was given in NATURE of October 27, 1898, on the occasion of the laying of the foundation-stone. As the size of the new building surpasses that of any other physical laboratory in this country, it was fittıng that the occasion should be marked by a ceremony of some importance, and dignified by the presence of a number of leading physicists from all parts of the country.

The main features of the new laboratories, as planned by Prof. Schuster, were described in our former article ; but it remains to state how they have been carried out. The new building is separated by Coupland Street from the main quadrangle of buildings of which Owens College consists, though it is joined to the older buildings by an underground passage. It is a commodious structure, having three complete storeys above the basement, with simple but effective decorative features both internal and external. The frontage is about I Io feet wide, and the main building extends about 90 feet back. The ground floor is devoted to rooms for electrical measurement, the magnetic testing of iron, electrochemistry, a workshop and a private laboratory. The first floor contains a large laboratory for elementary teaching ( 36 feet by 44 feet in dimensions), a balance room, a room for chemical physics, two laboratories for electricity and one for optics. On the second floor is a fine lecture theatre with raised auditorium, preparation room, museum and apparatus room, a class-room and two smaller laboratories, and a special room fitted up for physical optics; its special feature being the equipment, designed by Sir Howard Grubb, necessary for working with a 6-inch Rowland grating. From this floor an upper staircase leads to a small astronomical observatory containing an excellent Io-inch equatorial by Cooke, the gift of Sir Thomas Bazley. In the basement are rooms for spectroscopic and photographic work, a cryogenic laboratory and a room for researches at constant temperature. The arrangements for heating, ventilating, and for the supply of gas, electricity, water, steam and compressed air are exceedingly complete. In the ventilation system, the air supplied through a fan and warmed by passage through a flue heated by the gases of the boiler-furnaces, is passed over a surface of oil to deprive it of its dust and prevent blackening effects.

A very important adjunct to this fine building is the John Hopkinson memorial wing for electrotechnics. This consists of two large rooms on the ground floor: one ( 27 feet by 50 feet) to serve as a dynamo room, the other an electrochemical laboratory ( 36 feet by 37 feet), together with basement rooms for gas engine, countershaft for dynamo-driving, photometers, and heating apparatus. In the dynamo room, where already are placed several of Wilde's dynamos and some more recent types, there is a fine bronze portrait tablet of the late Dr. Hopkinson. The cost of this wing has been defrayed by the parents and relations of the lamented Dr. Hopkinson, who was himself an alumnus of Owens College.

The opening ceremony on the 29 th ultimo began with 
an academic procession from the Christie library to the lecture theatre of the new laboratories, where the chair was taken by the Treasurer of Owens College, Mr. Alderman Thompson. Amongst those present were Lord Rayleigh, Prof. Schuster, Sir Henry Roscoe, Principal Hopkinson, Prof. Oliver J. Lodge, Prof. Bodington (Vice-Chancellor of Victoria University), Prof. Ruicker, Prof. Pickering of Harvard College, Prof. Osborne Reynolds, Prof. Stroud, Prof. J. J. Thomson, Prof. Poynting, Prof. Ramsay, Prof. Core, Archdeacon Wilson, Mr. Wimshurst, Prof. Perry, Mr. W. Mather, M.P., and many others. Lord Rayleigh delivered a short address upon physical laboratory work and research, and formally pronounced the building open. Prof. Schuster gave an account of the aims of the building, and of the various stages in their realisation. Prof. Pickering likened a physical laboratory to a battleship, and enlarged upon the uses of its equipment. The company then adjourned, some to visit the various rooms, others to attend the opening ceremony in the John Hopkinșon memorial wing, which was presented in a touching speech by Mr. Alderman Hopkinson on behalf of the family.

A garden-party held in the afternoon in the house of Prof. Schuster was followed in the evening by a reception and conversazione in the new building. In one of the rooms was a very interesting exhibit of some of the apparatus used by Joule, including two "current weighers," a tangent galvanometer, and a mercury pump. These have been presented to the Owens College by Mr. B. A. Joule. In another room Mr. T. Thorp showed his celluloid gratings and celluloid reproductions of Rowland's grating and of his own echelon grating. Mr. Wilde exhibited his magnetarium and a number of lunar photographs. The large electro-magnet presented by him was also shown in operation.

On the morning of the 3oth was the annual ceremony of conferring of degrees of the Victoria University. This took place in the Manchester Free Trade Hall, which was crowded with undergraduates and visitors. The Chancellor, Earl Spencer, presided with great dignity. Honorary degrees were conferred on Lord Rayleigh, Sir William Huggins, Sir William Abney, Sir William Roberts-Austen, Dr. T. E. Thorpe, Prof. Dewar, Prof. Forsyth, Mr. R. T. Glazebrook, Mr. Sidney Lee, Prof. E. Pickering, Prof. J. J. Thomson, and last on the father of the profession of electrical engineering, Mr. Henry Wilde. The ordinary degrees were then conferred upon the successful candidates of the year from the three constituent colleges-Owens College, Liverpool University College, and the Yorkshire College. A luncheon in the Town Hall, given by the Lord Mayor, was subsequently partaken of by the Chancellor, the new Honorary Doctors, the University Professors, and a large number of distinguished visitors.

It has been mentioned that the new physics laboratory exceeds in size any other similar building in England. It is, however, smaller than the physics laboratories of Baltimore, Darmstadt and Strassburg. Its cost has been defrayed by the generosity of private individuals.

\section{NOTES.}

Two deputations have recently waited upon Mr. Hanbury to put before him the two sides of the question referring to the proposed establishment of the National Physical Laboratory in the Old Deer Park at Richmond. On one side are some naturalists and inhabitants of the neighbourhood, who protest against the proposed buildings as an interference with the amenities of the neighbourhood of Kew Gardens; on the other are the physicists and the members of the Committee, which, after giving great attention to the question of site, decided that
Kew was most suitable. It is a little unfortunate that this difficulty should have arisen, and it could probably have been avoided by the exercise of a little tact and consideration when selecting the site for the laboratory. Much of the misapprehension which at present exists as to the character of a physical laboratory might thus have been removed. Some people seem to think that the fifteen acres required will be covered with buildings in which noisy operations comparable with those of large engineering workshops will be carried on. This, of course, is entirely incorrect. In the first place, the actual area to be covered by buildings is only a quarter of an acre, or the sixtieth part of the whole area proposed to be taken, and secondly, quiet and freedom from all the perturbing characteristics of towns and manufactories are essential for the investigations to be carried on in the laboratories. When this is kept in mind, the alarm of a certain portion of the public, especially those who appreciate the beauties of Kew Gardens, that the buildings would break the present charm. seems a trifle unnecessary. The Observatory being already in the Old Deer Park, it is natural and proper that the laboratory, which is under the same administration, should be there too. As, however, the Park is over $35^{\circ}$ acres in extent, it ought not to be difficult to find another suitable site if there is a persistent opposition to the one already selected. In any case, we are convinced that a modus vivendi could be arrived at if the representatives of the opposing interests were to meet one another in a conciliatory spirit.

M. Zambaco has been elected a correspondant of the Paris Academy of Sciences, in the section of medicine and surgery.

DR. CoRfinLD, professor of hygiene and public health at University College, has been elected a Foreign Corresponding Member of the Royal Academy of Medicine of Belgium.

Mr. J. H. MAIDEN, director of the Botanic Gardens, Sydney, is expected to arrive in London at the end of the present month, and will be in the United Kingdom and on the Continent for about three months, engaged in special investigations in botany and agriculture.

THE Duke of Northumberland has been elected a trustee of the British Musettm.

THE annual meeting of the Victoria Institute will be held on Monday next, July 16, when an address will be delivered by Prof. Hull, F.R.S.

IT is announced in the Athenaeum that Baron von Richthofen has been nominated Director of the newly founded Museum für Meereskunde of the University of Berlin.

A Botanic Garden has been established by the Belgian Government at Coquilhautville, Congo Free State. It will be called the Kew Gardens, and is expected to be of great importance to the rubber and other tropical industries.

THE Council of the Royal Geographical Society have decided to award the Murchison Grant for next year to Mr. John Coles, late Map Curator and Instructor to the Society, as an acknowledgment of his services to geography.

THE annual meeting of the Society of Chemical Industry will be held in the lecture theatre of the Royal Institution, Albe. marle Street, on Wednesday, July 18 , when the presidential address will be delivered, and the officers for the ensuing year appointed. The president-elect is Mr. J. W. Swan, F.R.S.

THE Council of the Sanitary Institute have arranged to hold a meeting in Paris from August 7 to 9, which will immediately precede the meeting of the International Congress of Hygiene and Demography, also to be held in Paris. The Société Francaise d'Hygiène have offered to the members of the Institute

NO. I6O2, VOL. 62] 